\title{
Pengaruh Kombinasi Pupuk NPK dan Pengapuran pada Tanah Gambut Rawa Pening terhadap Pertumbuhan Tanaman Tomat (Lycopersicon esculentum Mill)
}

\section{The Effect Combination NPK Fertilizer and Liming of Peat Soil to Tomato's Growth (Lycopersicon esculentum Mill)}

\author{
Amelia Lestari ${ }^{1}$, Endah Dwi Hastuti ${ }^{2}$, Sri Haryanti ${ }^{2}$ \\ ${ }^{1)}$ Program Studi Biologi, Departemen Biologi, Fakultas Sains dan Matematika, Universitas Diponegoro \\ ${ }^{2)}$ Departemen Biologi, Fakultas Sains dan Matematika, Universitas Diponegoro \\ Jl. Prof. Soedarto, SH, Tembalang, Semarang \\ *Email: amelialestari2@gmail.com
}

Diterima 17 Juli 2014 / Disetujui 24 Januari 2018

\begin{abstract}
ABSTRAK
Tanah gambut berasal dari dekomposisi bahan organik sehingga memiliki $\mathrm{pH}$ tanah yang asam dan kaya kadar C-organik. Pemanfaatan tanah gambut Rawa Pening saat ini masih sangat terbatas. Pemberian kombinasi pupuk NPK dan kapur dolomit sebagai upaya meningkatkan $\mathrm{pH}$ tanah, sehingga tanah gambut dapat dimanfaatkan sebagai media tanam yang baik bagi tanaman tomat. Tujuan penelitian ini mengetahui kombinasi pupuk NPK dan kapur dolomit terhadap pertumbuhan tanaman tomat yang optimum pada media tanah gambut.. Rancangan yang digunakan adalah Rancangan Acak Lengkap (RAL) pola faktorial dengan dua faktor yaitu konsentrasi pupuk NPK (P): tanpa pupuk NPK (P0), pupuk NPK 5 g/tanaman (P1), pupuk NPK $10 \mathrm{~g} / \operatorname{tanaman}(\mathrm{P} 2)$, pupuk NPK $15 \mathrm{~g} / \operatorname{tanaman}(\mathrm{P} 3)$ dan kapur dolomit (K): tanpa kapur dolomit (K0), kapur dolomit $15 \mathrm{~g} / \mathrm{tanaman}$ (P1), kapur dolomit $25 \mathrm{~g} /$ tanaman. Penelitian menggunakan 12 perlakuan masingmasing dengan 3 ulangan. Analisis data yang digunakan adalah Analisis of Variance (ANOVA) yang dilanjutkan dengan uji beda nyata Duncan's Multiple Range Test (DMRT) taraf kepercayaan 95 \%. Parameter yang diamati yaitu tinggi tanaman, jumlah daun, jumlah cabang, berat basah dan berat kering. Hasil penelitian menunjukkan bahwa secara statistik tidak berpengaruh. Terdapat interaksi antara pupuk NPK dan kapur dolomit terhadap berat basah dan berat kering tanaman tomat. Interaksi $5 \mathrm{~g} / \operatorname{tanaman}$ dan kapur dolomit 15 $\mathrm{g} / \mathrm{tanaman}$ menghasilkan berat basah dan berat kering yang optimal.
\end{abstract}

Kata kunci: tomat (Lycopersicon esculentum Mill), gambut, NPK, dolomit, pertumbuhan

\begin{abstract}
Peat soil is formed from the decomposition of organic material so it is acidic and rich of C-organic. The utilization of peat soil on Rawa Pening is still limited to certain usage. The application of NPK fertilizer and dolomite is an effort to increase the $\mathrm{pH}$ of the soil as the medium for tomato plants. The research was aimed to determine the ratio of NPK fertilizer and dolomite to the optimum growth of tomato plants on peat soil. The experiment was laid out in Complete Randomized Design (factorial) using two factors: the concentration of NPK fertilizer (P): without NPK fertilizer (P0), $5 \mathrm{~g}$ /plant of NPK fertilizer (P1), $10 \mathrm{~g}$ /plant of NPK fertilizer (P2), $15 \mathrm{~g} /$ plant of NPK fertilizer (P3). Second, the consentration of dolomite (K): without dolomite (K0), 15 $\mathrm{g} /$ plant of dolomite $(\mathrm{K} 1), 25 \mathrm{~g} /$ plant of dolomite (K2). The research was performed in 12 treatments with 3 replications. The analysis is done by applying ANOVA, followed by Duncan's test at the significance level of 95\%. The research parameter includes the height of plant, the number of leaves, the number of branch, the number of flowers, total fresh weight and total dry weight. The results,according statistical analysis shown that there is no significant effect. There is interaction of NPK fertilizer and lime to total fresh weight and total dry weight. The concentration NPK fertilizer $5 \mathrm{~g} /$ plant and dolomite $15 \mathrm{~g} / \mathrm{plant}$ show the optmum dry weight and wet weight.
\end{abstract}

Keywords: tomato (Lycopersicon esculentum Mill), peat, NPK, dolomite, growth. 


\section{PENDAHULUAN}

Tanah gambut di Indonesia menempati 10\% dari luas daratan Indonesia, yang ditaksir mencakup areal seluas 17 juta hektar dan merupakan nomor empat di dunia setelah Kanada, Rusia, USA. Penyebarannya sebagian besar di Sumatera seluas 4,3 juta Ha, Kalimantan seluas 9,3 juta Ha, dan Irian Jaya seluas 4,6 juta Ha. Luasnya lahan gambut ini adalah salah satu keuntungan bagi Indonesia karena lahan ini bisa digunakan sebagai media tanaman perkebunan, pertanian, hortikultura, dan tanaman obat-obatan (Barchia, 2006).

Bahan penyusun tanah gambut didominasi oleh bahan organik, yaitu sebesar $85 \%$ (Wibisono, 2005) dan terbentuk dari timbunan sisa-sisa tanaman, baik yang telah mengalami pelapukan maupun yang belum (Agus dan Subiksa, 2008). Dominasi bahan organik sebagai penyusun pada tanah gambut terlihat dari kadar C-organik sebesar 57,23\% dan N-total sebesar 1,2\%-1,8\% (Barchia, 2006).

Salah satu contoh tanah gambut di Pulau Jawa berada di Rawa Pening. Gambut di daerah Rawa Pening menjadi masalah karena dapat mempercepat proses pendangkalan rawa (Agung, 2001). Pemanfaatan gambut Rawa Pening saat ini masih sangat terbatas, sehingga proses pendangkalan rawa terus berlangsung. Karakteristik gambut Rawa Pening adalah bahan gambutnya yang berasal dari tanaman non-kayu, sehingga memiliki $\mathrm{pH}$ yang tidak terlalu masam. Tanah gambut Rawa Pening merupakan hasil dekomposisi limbah eceng gondok. Menurut Kristijono (2010) pH tanah gambut Rawa Pening sebesar 5 hingga 5,5. Kondisi tanah dengan $\mathrm{pH} 5$ 5,5 masih tergolong agak asam sehingga bagi tanaman kurang baik karena ketersediaan hara tidak dapat diserap oleh tanaman.

Tomat merupakan tanaman hortikultura yang memiliki daerah sebaran sangat luas, mulai dari daerah tropis hingga subtropis. Varietas atau jenisnya juga cukup banyak (Agromedia, 2007). Tomat merupakan sayuran popular di Indonesia. Buah tomat saat ini merupakan salah satu komoditas hortikultura yang bernilai ekonomi tinggi dan masih memerlukan penanganan serius terutama dalam meningkatkan kuantitas dan kualitas buahnya. Sejak tahun 2008-2010 diketahui bahwa produksi tomat di Indonesia mulai terjadi adanya peningkatan, hingga tahun 2011 mencapai produksi 954,046 Ton. Namun tahun 2012 mengalami penurunan 887,556 Ton. Data impor tomat hingga tahun 2013 mengalami kenaikan hingga 26\%. Namun data ekspor tomat di Indonesia hanya sekitar $1 \%$ dari total produksi (BPS, 2013).

Tomat yang secara umum dapat ditanam tanpa mengenal musim dan pada tanah dengan keasaman (pH) 5-6. Sedangkan tanah gambut Rawa Pening memiliki kadar keasaman (pH) 5-5,5 yang merupakan hasil dekompisisi limbah eceng gondok dengan keberadaannya yang melimpah dan pemanfaatan tanah gambut Rawa Pening saat ini masih terbatas. Tanah gambut Rawa Pening tergolong masam sehingga menyebabkan ketidaksuburan tanah.

Ketidaksuburan tanah masam daerah tropis, atau rendahnya produktivitas tanah masam daerah tropis, pada umumnya di samping oleh faktor kemasaman tanah juga disebabkan karena $\mathrm{P}$ rendah dan daya fiksasi fosfor yang tinggi, kemudian daya keracunan oleh ion Fe dan $\mathrm{Al}$ yang tinggi, KTK rendah, kejenuhan basa (terutama $\mathrm{Ca}$ dan $\mathrm{Mg}$ ) yang rendah, dan hasil pelapukan bahan organik tercuci (Absori, 2009). Reaksi tanah pada pengelolaan tanah yang ditunjukkan oleh tingkat kemasaman atau $\mathrm{pH}$ sangat menentukan keberhasilan budidaya tanaman pertanian.

Upaya pengelolaan lahan gambut dapat dilakukan dengan drainase, pengelolaan struktur, pengapuran dan penggunaan unsur mikro (Soepardi, 1983). Drainase lahan gambut merupakan penurunan dan pengendalian air di area lahan gambut dalam jangka waktu relatif lama untuk memungkinkan terjadinya aerasi pada daerah akar selama musim pertanaman. Pengelolaan struktur tanah gambut dapat dilakukan dengan pemadatan, makin lama gambut diusahakan pemadatan makin penting. Dalam peningkatan kejenuhan basa tanah, pemberian kapur umum dilakukan terutama mengandung $\mathrm{CaCO}_{3}$ dan $\mathrm{MgO}_{3}$ (Subiksa et al., 1991 dalam Agus dan Subiksa, 2008) 
Pengapuran selain dapat mengurangi kemasaman tanah juga meningkatkan kandungan kation basa yaitu $\mathrm{Ca}$ dan $\mathrm{Mg}$ maupun kejenuhan basa gambut. Pengapuran mempengaruhi pertumbuhan tanaman melalui dua cara yaitu peningkatan ketersediaan unsur $\mathrm{Ca}, \mathrm{Mg}$, dan perbaikan ketersediaan unsur-unsur lain yang ketersediaannya tergantung $\mathrm{pH}$ tanah. Dolomit merupakan salah satu jenis kapur yang mengandung $\mathrm{Ca}$ dan $\mathrm{Mg}$. Kedua unsur ini penting untuk menunjang pertumbuhan dan perkembangan tanaman (Driessen, 1978 dalam Nurhayati, 2008).

Ketersediaan hara pada tanah gambut tergolong rendah sehingga perlu dilakukan pemupukan. Marsono dan Sigit (2002) menyatakan bahwa manfaat pupuk secara umum adalah menyediakan unsur hara yang kurang atau bahkan tidak tersedia di tanah untuk mendukung pertumbuhan tanaman. Atas dasar kandungan unsur hara yang dikandungnya pupuk terdiri dari pupuk tunggal dan pupuk majemuk. Pupuk tunggal adalah pupuk yang mengandung satu jenis hara tanaman seperti $\mathrm{N}$ atau $\mathrm{P}$ atau $\mathrm{K}$ saja, sedangkan pupuk majemuk adalah pupuk yang mengandung lebih dari satu unsur hara tanaman, seperti gabungan antara $\mathrm{N}$ dan $\mathrm{P}, \mathrm{N}$ dan $\mathrm{K}$ atau $\mathrm{N}$ dan $\mathrm{P}$ dan K (Sabiham et al, 1989).

Penelitian ini menggunakan pupuk NPK dan kapur dolomit untuk pengelolaan tanah gambut Rawa Pening sebagai media tanam tanaman tomat. Penggunaan tanah gambut Rawa Pening bertujuan untuk pemanfaatan tanah gambut Rawa Pening saat ini masih terbatas yang merupakan hasil dekompisisi limbah eceng gondok dengan keberadaannya yang melimpah. Pengelolaan tanah gambut Rawa Pening dengan pupuk NPK dan kapur dolomit untuk mengatasi permasalahan kemasaman tanah, tingginya ketersediaan $\mathrm{Al}$ dan $\mathrm{Fe}$ dan rendahnya unsur hara yang dibutuhkan tanaman terutama hara makro.

\section{METODE PENELITIAN}

Pengambilan tanah gambut di Rawa Pening pada bulan Agustus 2013. Penelitian dilakukan di Tlogosari, Kecamatan Tembalang, Kabupaten Semarang dan Laboratorium BSF Tumbuhan, Departemen Biologi Fakultas Sains dan
Matematika Universitas Diponegoro. Waktu penelitian dilaksanakan pada bulan Agustus sampai dengan November 2013. Bahan-bahan yang digunakan adalah tanah gambut Rawa Pening, bibit tanaman tomat (Lycopersicon esculentum Mill.), pupuk NPK, pupuk kandang, tanah liat, kapur dolomit, arang sekam, pestisida, air, aquades dan label. Alat-alat yang digunakan pada penelitian ini yaitu kertas pHmeter, kantong polibag berukuran $15 \times 15 \mathrm{~cm}$ dan $25 \times 25 \mathrm{~cm}$, plastik, meteran, neraca Ohauss, neraca digital, oven, karung, tampah plastik, cawan petri, hand sprayer, selang, cetok, bambu, penggaris, alat tulis, gunting, toples plastik kecil, sarung tangan, masker dan kamera.

\section{Pengambilan Sampel Tanah Gambut}

Sampel tanah gambut di Rawa Pening diambil gambut yang berada di tengah rawa. Tanah gambut yang telah diambil dimasukkan ke dalam karung. Setelah sampai di kebun percobaan, sampel dipindah ke dalam kantong polibag berukuran $25 \times 25 \mathrm{~cm}$. Tanah gambut Rawa Pening digunakan sebagi media utama penanaman tanaman tomat.

\section{Penyiapan pupuk NPK}

Susila (2006) merekomendasikan pemupukan NPK pada tanaman tomat dengan dosis $10 \mathrm{~g} /$ tanaman pada $\mathrm{pH}$ 6,5 diberikan dengan cara ditaburkan pada media tanam dengan diberikan 4 kali untuk sekali panen, yaitu 3 hari sebelum transplanting (20\%), 7 hari pasca transplanting (40\%) dan 30 hari pasca transplanting (20\%) dan 60 hari pasca transplanting (20\%). Berdasarkan acuan kebutuhan pupuk NPK tersebut maka dalam penelitian digunakan pupuk NPK yang ditimbang yaitu dengan takaran $5 \mathrm{~g} /$ tanaman, $10 \mathrm{~g} /$ tanaman dan $15 \mathrm{~g} /$ tanaman.

\section{Penimbangan kapur Dolomit}

Kapur dolomit yang digunakan disesuaikan dengan derajat keasaman tanah. Menurut Balai Penelitian Tanah (2011) tanah dengan derajat keasaman 4,5 (terlalu asam): kebutuhan dolomit 25 
g/tanaman dan derajat keasaman 5,5 (asam): membutuhkan dolomit $15 \mathrm{~g} /$ tanaman. Berdasarkan acuan membutuhkan kapur tersebut maka dalam penelitian digunakan kapur sebesar $15 \mathrm{~g} /$ tanaman dan $25 \mathrm{~g} /$ tanaman. Pemberian dolomit dilakukan dua minggu sebelum penanaman tomat dengan penghalusan agregat tanah sehingga tercampur merata pada media tanam.

\section{Penyemaian benih Tomat}

Penyemaian dilakukan dengan tahapan sebagai berikut: Media semai merupakan campuran tanah liat dan pupuk kandang (1:1). Media tersebut dimasukkan ke dalam polibag plastik berukuran $15 \times 15 \mathrm{~cm}$, selanjutnya dilakukan penyebaran benih sebanyak 20 benih/polibag secara merata pada permukaan media dan ditutup tipis dengan arang sekam untuk menjaga kelembaban benih sebelum berkecambah. Bibit berumur 30 hari untuk bahan perlakuan diseleksi dengan kriteria sehat, berdaun empat dan tinggi sama.

\section{Penyiapan media perlakuan}

Perlakuan pupuk NPK diberikan 3 kali, yaitu 3 hari sebelum transplanting dengan dosis $20 \%$ dari dosis perlakuan, 7 hari pasca transplanting dengan dosis $40 \%$ dari dosis perlakuan dan 30 hari pasca transplanting dengan dosis $40 \%$ dari dosis perlakuan. Perlakuan pupuk NPK yang digunakan dengan 4 taraf yaitu: 0 $\mathrm{g} / \mathrm{tanaman}, 5 \mathrm{~g} / \mathrm{tanaman}, 10 \mathrm{~g} / \mathrm{tanaman}$ dan 15 g/tanaman. Pemberian dolomit dilakukan dua minggu sebelum penanaman tomat dengan penghalusan agregat tanah sehingga tercampur merata pada separuh permukaan media tanam.

\section{Penanaman}

Penanaman dilakukan dengan memindahkan bibit tomat terpilih ke polibag berukuran $25 \times 25$ $\mathrm{cm}$. Penanaman dilakukan pada sore hari untuk menghindari panas matahari pada waktu siang hari yang dapat menyebabkan bibit menjadi layu. Penanaman dilakukan pada media tanah gambut perlakuan dengan membenamkan bibit secara dangkal pada batas pangkal batang. Selesai penanaman langsung dilakukan penyiraman.
Penyiraman dilakukan setiap hari selama 6 MST (Minggu Setelah Tanam).

\section{Pemeliharaan tanaman}

Pemeliharaan yang dilakukan adalah penyiraman secara teratur pada pagi hari, penyiangan gulma yang tumbuh disekitar bibit sampai bibit tomat berumur 6 MST. Penyemprotan pestisida Decis dengan dosis $0,25 \mathrm{~mL} / 1 \mathrm{~L}$ aquades dilakukan karena terdapat kutu putih pada bibit tomat berumur 4 MST.

\section{Parameter Penelitian}

Sebelum perlakuan dilakukan uji/analisis tanah gambut rawa Pening untuk mengetahui kondisi/status tanah awal. Parameter yang diuji adalah $\mathrm{C} / \mathrm{N}$ rasio, kandungan Nitrogen dan bahan organik. Parameter yang diamati pada penelitian ini adalah: tinggi tanaman, jumlah daun, jumlah cabang, jumlah bunga, berat basah dan berat kering tanaman tomat.

\section{Rancangan Penelitian}

Penelitian ini menggunakan Rancangan Acak Lengkap (RAL) pola faktorial (factorial ANOVA) yaitu faktor 1 pupuk NPK ( $\mathrm{P} 0=$ tanpa perlakuan NPK; P1= NPK 5 g/tanaman; P2= NPK $10 \mathrm{~g} /$ tanaman; P3= NPK $15 \mathrm{~g} /$ tanaman) dan faktor 2 dolomit $(\mathrm{K} 0=12$ tanpa pengapuran; $\mathrm{K} 1=15$ $\mathrm{g} /$ tanaman; K2 $=25 \mathrm{~g} /$ tanaman) masing-masing perlakuan dengan 3 ulangan. Data yang diperoleh dianalisis dengan ANOVA, apabila menunjukkan hasil yang signifikan dilanjutkan dengan uji Duncan Multiple Range Test (DMRT) pada taraf kepercayaan $95 \%$.

\section{HASIL DAN PEMBAHASAN}

\section{Sifat Kimia Tanah Gambut sebelum Perlakuan}

Hasil analisis tanah gambut Rawa Pening sebelum perlakuan menunjukkan bahwa nilai $\mathrm{pH}$ kisaran 5-5.5. Menurut Buckman dan Brady (1982), secara umum kompleks koloid gambut dipengaruhi oleh hidrogen yang menyebabkan $\mathrm{pH}$ tanah gambut lebih rendah daripada tanah mineral. 
Tanah gambut mengalami pencucian hara dan bersifat asam disebabkan oleh tercucinya basabasa dari komplek hara serapan dan hilang melalui drainase. Pencucian basa-basa meninggalkan kation $\mathrm{Al}$ dan $\mathrm{H}$ sebagai kation dominan sehingga tanah mengandung $\mathrm{Al}$ dan $\mathrm{Fe}$ terlarut dalam jumlah besar.

Hasil analisis bahan organik, $\mathrm{N}$ total, $\mathrm{C} / \mathrm{N}$ rasio tanah gambut Rawa Pening sebelum perlakuan tersaji pada Tabel 1. Kandungan bahan organik $(7,50 \%)$ dan $\mathrm{N}$-total $(0,95 \%)$ tanah gambut Rawa Pening sebelum perlakuan tergolong tinggi. Menurut Hardjowigeno (2003) bahan organik dengan standar tinggi adalah lebih dari $5 \%$ dan $\mathrm{N}$ total $0,51-1 \%$. Ketersediaan $\mathrm{N}$ bagi tanaman dipengaruhi oleh beberapa faktor, antara lain oleh rasio $\mathrm{C} / \mathrm{N}$. Hasil analisis, rasio $\mathrm{C} / \mathrm{N}$ tanah gambut dari Rawa Pening dalam penelitian ini tergolong rendah $(4,60)$ karena menurut Hardjowigeno (2003) standar $\mathrm{C} / \mathrm{N}$ rasio adalah 5-10. Hal ini diduga karena tanah gambut Rawa Pening mengandung bahan organik yang terbentuk dari sisa-sisa tanaman yang sudah terdekomposisi. Menurut Absori (2009) unsur hara pada tanah gambut Rawa Pening tergolong rendah ditinjau dari kemasaman tanah dan kandungan $\mathrm{P}$ rendah serta daya fiksasi fosfor yang tinggi. Selain itu, tanah gambut juga mempunyai daya keracunan oleh ion $\mathrm{Fe}$ dan $\mathrm{Al}$ yang tinggi, KTK rendah, kejenuhan ion (terutama $\mathrm{Ca}$ dan $\mathrm{Mg}$ ) rendah dan hasil pelapukan bahan organik tercuci.

Tabel 1. Analisis Nitrogen, Bahan organik dan $\mathrm{C} / \mathrm{N}$ rasio tanah gambut Rawa Pening sebelum perlakuan

\begin{tabular}{cccc}
\hline & \multicolumn{3}{c}{ Parameter Uji } \\
\cline { 2 - 4 } Tanah & Nitrogen & Bahan & \\
Gambut & $(\%)$ & $\begin{array}{c}\text { Organik } \\
(\%)\end{array}$ & Rasio C/N \\
Rawa Pening & 0,95 & 7,50 & 4,60 \\
\cline { 2 - 4 } & &
\end{tabular}

\section{Derajat Keasaman (pH) Media Perlakuan}

Hasil analisis $\mathrm{pH}$ tanah gambut Rawa Pening dengan perlakuan kapur dolomit tersaji pada Tabel 2.Perlakuan pengapuran meningkatkan pH tanah gambut Rawa Pening. Perlakuan yang menghasilkan $\mathrm{pH}$ tanah paling tinggi adalah pada K2. Pengapuran dolomit mampu mengatasi kemasaman tanah sehingga tingkat derajat kemasaman tanah tidak membahayakan bagi pertumbuhan tanaman.

Tabel 2. pH mediatanah gambut setelah perlakuan kapur dolomit

\begin{tabular}{cc}
\hline Media Penanaman & $\mathrm{pH}$ \\
\hline K0 & $5,33^{\mathrm{b}}$ \\
K1 & $6,67^{\mathrm{a}}$ \\
K2 & $7,00^{\mathrm{a}}$ \\
\hline
\end{tabular}

Keterangan : *Angka-angka yang diikuti huruf yang berbeda menunjukkan hasil berbeda nyata berdasarkan hasil uji Duncan's pada taraf signifikasi $95 \%$. K0 $=12$ tanpa pengapuran; $\mathrm{K} 1=15 \mathrm{~g} / \mathrm{tanaman} ; \mathrm{K} 2=25 \mathrm{~g} / \operatorname{tanaman}$

\section{Perlakuan pengapuran mampu} meningkatkan $\mathrm{pH}$ tanah gambut Rawa Pening dengan rerata 6.67 dan 7.00 diduga karena $\mathrm{Al}$ sudah ternetralisasi. Aluminium dari mineral liat yang digantikan oleh kation lain akan terhidrolisis menjadi senyawa kompleks aluminium hidroksida yang berupa endapan yang tidak meracuni tanaman. Mansur (2000) menjelaskan bahwa reaksi kapur dolomit $\mathrm{CaMg}\left(\mathrm{CO}_{3}\right)_{2}$ di dalam tanah secara sederhana sebagai berikut:

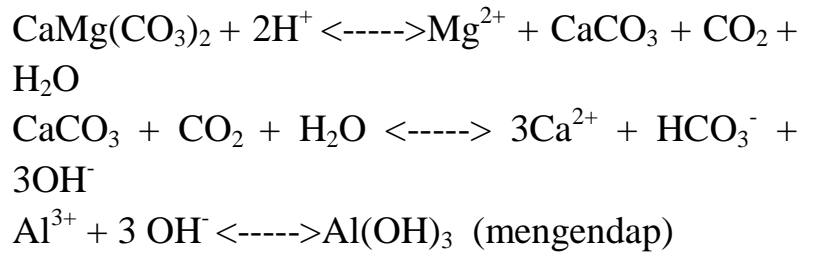
$3 \mathrm{OH}^{-}$

$\mathrm{Al}^{3+}+3 \mathrm{OH}^{-}<----->\mathrm{Al}(\mathrm{OH})_{3}$ (mengendap) 
$\mathrm{Al}^{3+}$ yang berasal dari larutan tanah akan bereaksi dengan $\mathrm{OH}^{-}$dari hasil reaksi bahan kapur sehingga membentuk endapan $\mathrm{Al}(\mathrm{OH})_{3}$. Dengan demikian pemberian bahan kapur mengakibatkan pengendapan $\mathrm{Al}$ dalam bentuk $\mathrm{Al}(\mathrm{OH})_{3}$ dan pada saat yang sama $\mathrm{pH}$ akan meningkat. Pengapuran dapat menetralkan senyawa-senyawa beracun di dalam tanah. Soepardi (1983) menyatakan bahwa aminisasi, amonifikasi dan oksidasi belerang dipercepat dengan meningkatnya $\mathrm{pH}$ yang diakibatkan oleh pengapuran. Dengan demikian keracunan $\mathrm{Al}$ dapat teratasi sehingga pertumbuhan tanaman akan baik.

\section{Pengaruh Pupuk NPK terhadap Pertumbuhan Tanaman Tomat}

Tabel 3 menunjukkan bahwa meskipun secara statistik pupuk NPK tidak berpengaruh terhadap pertumbuhan tanaman tetapi ada kecenderungan peningkatan terhadap tinggi tanaman, jumlah daun, jumlah cabang dan jumlah bunga dibandingkan dengan kontrol. Media tanam dengan perlakuan pupuk NPK menunjukkan peningkatan sampai P1 dan mengalami penurunan dengan peningkatan dosis pada $\mathrm{P} 2$ dan $\mathrm{P} 3$, hal ini tersaji pada Gambar 1, 2, 3 dan 4.

Tabel 3. Rerata pengaruh pupuk NPK terhadap pertumbuhan tanaman tomat pada umur 6 MST

\begin{tabular}{ccccc}
\hline & \multicolumn{4}{c}{ Parameter } \\
\cline { 2 - 5 } Perlakuan & $\begin{array}{c}\text { Tinggi } \\
\text { Tanaman } \\
(\mathrm{cm})\end{array}$ & $\begin{array}{c}\text { Jumlah } \\
\text { Daun }\end{array}$ & $\begin{array}{c}\text { Jumlah } \\
\text { Cabang }\end{array}$ & $\begin{array}{c}\text { Jumlah } \\
\text { Bunga }\end{array}$ \\
\hline P0 & 20,69 & 6,90 & 0,67 & 2,50 \\
P1 & 31,63 & 8,54 & 1,67 & 5,38 \\
P2 & 28,60 & 7,17 & 1,00 & 4,33 \\
P3 & 29,50 & 7,25 & 0,67 & 2,67 \\
\hline
\end{tabular}

Keterangan : $\mathrm{P} 0=$ tanpa perlakuan NPK; $\mathrm{P} 1=\mathrm{NPK} 5 \mathrm{~g} / \operatorname{tanaman} ; \mathrm{P} 2=\mathrm{NPK} 10 \mathrm{~g} / \mathrm{tanaman} ; \mathrm{P} 3=\mathrm{NPK} 15 \mathrm{~g} / \mathrm{tanaman}$

Secara umum pengamatan penggunaan pengaruh pupuk NPK $5 \mathrm{~g}$ (P1) pada tanah gambut Rawa Pening sebagai media penanaman menunjukkan pertumbuhan tanaman tomat relatif lebih tinggi (Gambar 1, 2, 3 dan 4) dibandingkan dengan perlakuan kontrol (P0), pupuk NPK $10 \mathrm{~g}$ (P2) dan pupuk NPK 15 g (P3). Hal ini diduga bahwa pupuk NPK $5 \mathrm{~g}$ (P1) sudah mampu memperbaiki kondisi kesuburan tanah gambut Rawa Pening dan menciptakan kondisi kesuburan tanah untuk mendukung pertumbuhan dan perkembangan tanaman. Hal tersebut memungkinkan ketersediaan unsur hara optimum untuk pertumbuhan tanaman. Pemberian pupuk NPK 5 g (P1) menyediakan unsur hara yang dibutuhkan tanaman dan mampu memperbaiki kesuburan tanah gambut. Unsur hara yang terdapat dalam pupuk NPK pada P1 diperlukan oleh pertumbuhan dan perkembangan tanaman diserap oleh tanaman dalam bentuk anion dan kation.

Kecenderungan pertumbuhan tanaman tomat terendah diperoleh pada perlakuan kontrol atau tanpa pemberian pupuk NPK (P0). Hal ini dapat dilihat dari rata-rata tinggi tanaman (Gambar 1), jumlah daun (Gambar 2), jumlah cabang (Gambar 3) maupun jumlah bunga (Gambar 4). Perlakuan tanpa pemberian pupuk NPK berakibat pada kurang tersedianya unsur hara yang dibutuhkan oleh tanaman tomat, sehingga pertumbuhan menjadi tidak maksimal terlebih dengan kondisi tanah gambut Rawa Pening yang kurang subur dan memiliki pH agak asam.

\section{Pengaruh Pupuk NPK terhadap Pertumbuhan Tanaman Tomat}

Tabel 4 menunjukkan bahwa pengapuran ada kecenderungan penurunan terhadap tinggi tanaman, jumlah daun, jumlah cabang dan jumlah bunga dibandingkan dengan kontrol. Media dengan perlakuan kapur dolomit berpengaruh menurunkan pertumbuhan tanaman tomat dengan semakin meningkatnya konsentrasi yang diberikan. Hal ini tersaji pada Gambar 5, 6, 7 dan 8. 
Tabel 4 Rerata pengaruh kapur dolomit terhadap pertumbuhan tanaman tomat pada umur 6 MST.

\begin{tabular}{ccccc}
\hline & \multicolumn{4}{c}{ Parameter } \\
\cline { 2 - 5 } Perlakuan & $\begin{array}{c}\text { Tinggi } \\
\text { Tanaman } \\
(\mathrm{cm})\end{array}$ & $\begin{array}{c}\text { Jumlah } \\
\text { Daun }\end{array}$ & $\begin{array}{c}\text { Jumlah } \\
\text { Cabang }\end{array}$ & $\begin{array}{c}\text { Jumlah } \\
\text { Bunga }\end{array}$ \\
\hline K0 & 29,469 & 7,678 & 1,25 & 5,04 \\
K1 & 27,996 & 7,512 & 0,75 & 3,19 \\
K2 & 25,355 & 7,214 & 1,00 & 2,94 \\
\hline
\end{tabular}

Keterangan : K0= 12 tanpa pengapuran; $\mathrm{K} 1=15 \mathrm{~g} / \mathrm{tanaman} ; \mathrm{K} 2=25 \mathrm{~g} / \operatorname{tanaman}$

Secara umum pengamatan pada media kontrol atau tanpa perlakuan kapur dolomit (K0) pada tanah gambut Rawa Pening sebagai media penanaman menunjukkan pertumbuhan tanaman tomat relatif lebih tinggi dibandingkan media dengan perlakuan kapur dolomit $15 \mathrm{~g}$ dan $25 \mathrm{~g}$ (K1 dan K2). Hal ini diduga bahwa pengapuran hanya meningkatkan $\mathrm{pH}$ kondisi tanah gambut dan menyediakan unsur $\mathrm{Ca}$ dan $\mathrm{Mg}$. Ketersediaan unsur $\mathrm{Ca}$ dan $\mathrm{Mg}$ bukan hara esensial utama yang dibutuhkan tanaman untuk pertumbuhan. Mehlich dan Drake (1955) menjelaskan $\mathrm{Ca}$ berperan mengatur kemasaman tanah, pertumbuhan akar tanaman dan menetralisasi akumulasi racun dalam tubuh tanaman. Magnesium berperan menyehatkan klorofil dan mengatur peredaran zat $\mathrm{N}, \mathrm{P}$ dan karbohidrat dalam tubuh tanaman.

Kapur banyak mengandung unsur $\mathrm{Ca}$ tetapi pemberian kapur ke dalam tanah pada umumnya bukan karena tanah kekurangan $\mathrm{Ca}$ melainkan karena tanah terlalu masam. Media tanpa perlakuan kapur dolomit (K0) menunjukkan pertumbuhan tomat cenderung optimal juga karena tanaman dapat tumbuh pada $\mathrm{pH} 5$ karena menurut Wiryanta (2003) tomat secara umum sudah dapat ditanam pada tanah dengan $\mathrm{pH}$ 5-6. Hal ini diduga bahwa tanaman tomat toleran pada kisaran $\mathrm{pH}$ 5-6 meskipun pemberian kapur dapat meningkatkan $\mathrm{pH}$.

\section{Berat Basah dan Berat Kering Tanaman Tomat}

Hasil ANOVA menunjukkan pupuk NPK dan kapur dolomit pada konsentrasi yang berbeda berpengaruh nyata $(p>0,05)$ serta tidak terdapat interaksi diantara keduanya terhadap berat basah dan berat kering tanaman tomat (Gambar 1 dan 2).
Hasil pengamatan berat basah dan berat kering tanaman tomat (Gambar 9 dan Gambar 10) yang ditanam pada media tanam dengan perlakuan pupuk NPK 5 g dan kapur dolomit 15 g (P1K1) menunjukkan berat basah dan berat kering lebih besar dibandingkan dengan media perlakuan yang lain. Perlakuan pupuk dan pengapuran meningkatkan berat basah dan berat kering tanaman tomat. Perlakuan yang menghasilkan berat basah dan berat kering tanaman paling tinggi adalah pada pengapuran dengan pemupukan $5 \mathrm{~g}$ (P1) dan menurun dengan peningkatan dosis pupuk.

Perlakuan pupuk NPK $5 \mathrm{~g}$ dan kapur dolomit $15 \mathrm{~g}$ (P1K1) menunjukkan berat basah dan berat kering lebih besar dibandingkan dengan media perlakuan yang lain diduga karena perlakuan $\mathrm{K} 1$ mampu meningkatkan $\mathrm{pH}$ tanah gambut dari 5 menjadi 6 sehingga kelarutan ion optimal dan didukung dengan pemberian P1 optimal menyediakan unsur hara yang dibutuhkan tanaman. Sehingga perlakuan P1K1 menghasilkan kondisi yang optimal untuk pertumbuhan tanaman tomat. Kondisi pH 6 optimal untuk meningkatkan pertumbuhan tanaman tomat.

Hal ini sesuai dengan pernyataan Wiryanta (2003) yaitu $\mathrm{pH}$ tanah ideal dan optimal untuk tanaman tomat berkisar antara 6-7. Peningkatan $\mathrm{pH}$ mampu meningkatkan penyerapan unsur hara optimal seperti hara makro N dan P. Optimalnya penyerapan unsur hara didukung dengan penambahan unsur $\mathrm{N}, \mathrm{P}$ dan $\mathrm{K}$ sehingga dapat meningkatkan laju pertumbuhan tanaman. Lebih lanjut dikemukakan oleh Foth (1994) bahwa kelimpahan nitrogen mendorong pertumbuhan yang cepat dengan perkembangan daun, yang 
berwarna hijau tua, batang yang lebih besar serta mendorong pertumbuhan vegetatif di atas tanah.

Berat basah lebih tinggi pada perlakuan P1K1 diduga karena fotosintesis dan penyerapan hara pada tanaman tomat berlangsung optimal pada media dengan pemberian pupuk NPK $5 \mathrm{~g}$ dan kapur dolomit $15 \mathrm{~g}$ (P1K1). Pengangkutan oleh air mengakibatkan laju pengangkutan hara lebih cepat dan menjaga turgiditas sel tanaman tomat agar tetap optimal pada media P1K1. Unsur hara dan air yang tersedia pada media P1K1 akan digunakan untuk proses-proses pertumbuhan yang terjadi di dalam tanaman, seperti pemanjangan sel, pembelahan sel sehingga pertumbuhan tanaman akan meningkat akibat dari hasil aktivitas sel di dalam tanaman.

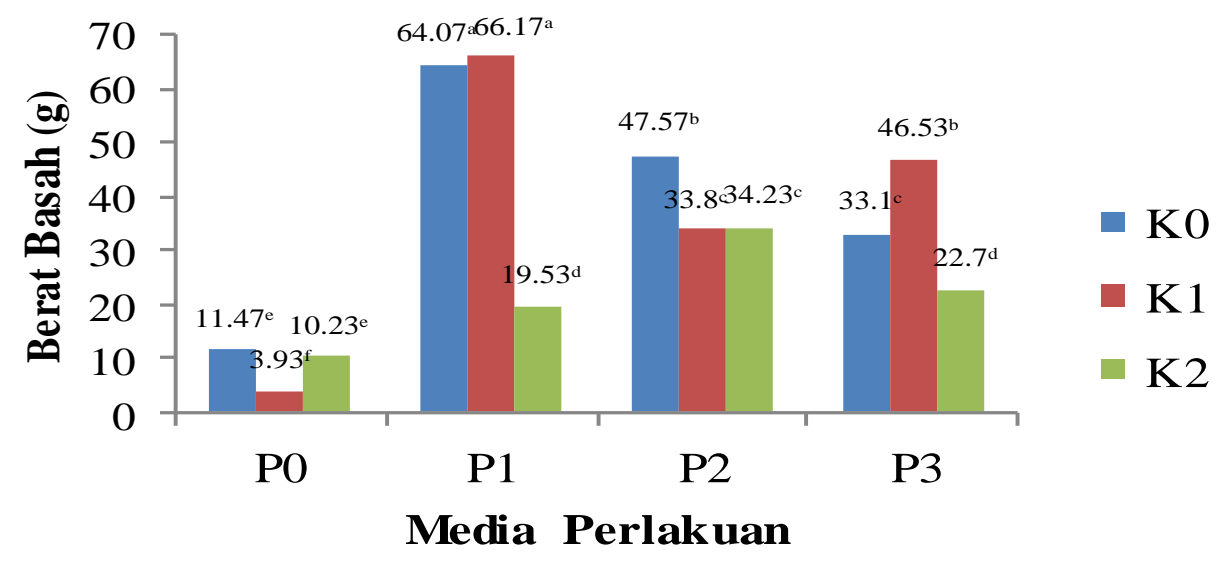

Gambar 1. Histogram rerata berat basah tanaman tomat dengan penambahan campuran pupuk NPK dan kapur dolomit yang berbeda

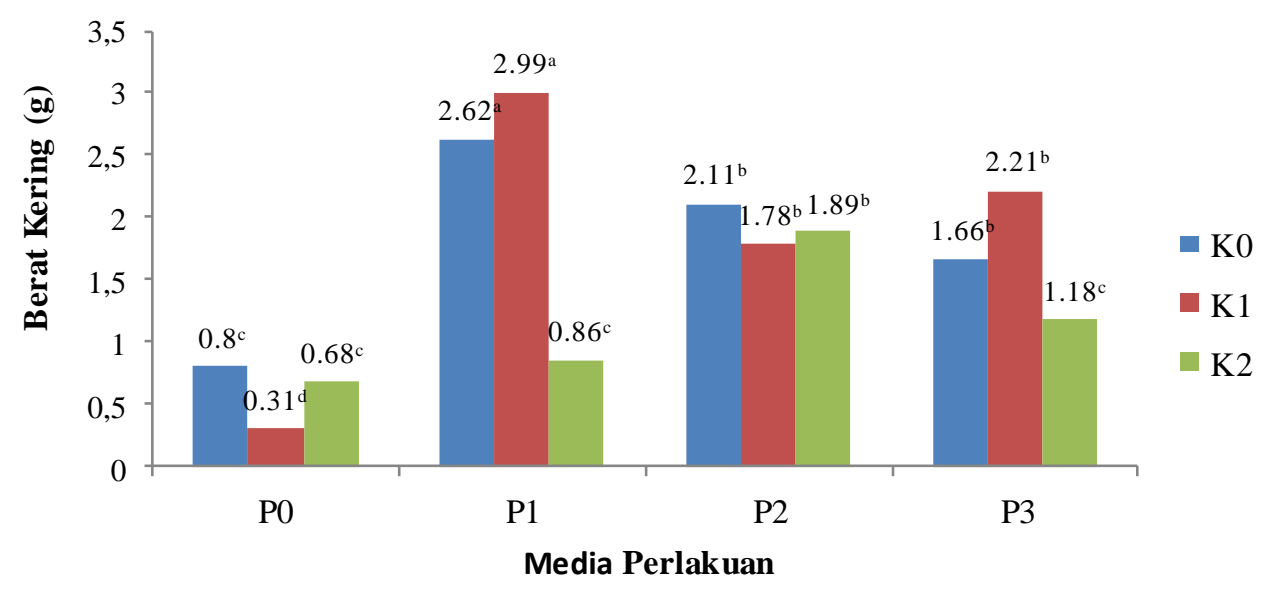

Gambar 2. Histogram rerata berat kering tanaman tomat dengan penambahan campuran pupuk NPK dan kapur dolomit yang berbeda

Berat basah merupakan peningkatan biomassa tanaman dipengaruhi oleh banyaknya absorpsi air, kemampuan tanaman menyerap unsur hara dan penimbunan hasil fotosintesis yang dibutuhkan dalam proses fisiologisnya. Fotosintat yang dihasilkan lebih banyak ditranslakosikan untuk organ tanaman yaitu diantaranya adalah daun dan batang (Salisbury \& Ross, 1995).

Secara umum hasil pengamatan berat kering tanaman tomat (Gambar 4.8) yang ditanam pada media tanam dengan perlakuan pupuk NPK $5 \mathrm{~g}$ dan kapur dolomit $15 \mathrm{~g}$ (P1K1) menunjukkan berat 
kering paling besar dibandingkan dengan media perlakuan yang lain. Hal ini diduga karena adanya penyerapan hara yang optimal oleh tanaman tomat karena media memiliki derajat keasaman $(\mathrm{pH}) 6$ yang artinya optimal untuk tanaman tomat. Berat basah dan berat kering paling rendah pada tanaman tomat dihasilkan pada media yang diberi kapur dolomit $15 \mathrm{~g}$ dan tanpa pemupukan (P0K1) diduga karena tidak mendapat tambahan hara $\mathrm{N}, \mathrm{P}$ dan $\mathrm{K}$ yang dibutuhkan tanaman untuk pertumbuhan. Kelarutan hara dari tanah gambut tidak cukup untuk mendukung pertumbuhan tanaman yang optimal. Pengapuran yang diberikan hanya mengatasi kemasaman tanah karena keracunan $\mathrm{Al}$ dan Fe. Aluminium dari mineral liat yang digantikan oleh kation lain akan terhidrolisis menjadi senyawa kompleks aluminium hidroksida yang berupa endapan yang tidak meracuni tanaman.

\section{KESIMPULAN}

1. Pemupukan NPK cenderung meningkatkan pertumbuhan tanaman tomat yaitu tinggi tanaman, jumlah daun, jumlah cabang dan jumlah bunga dengan dosis yang optimal adalah $5 \mathrm{~g} /$ tanaman kemudian menurun dengan peningkatan dosis.

2. Pengapuran dolomit cenderung menurunkan pertumbuhan tanaman tomat yaitu tinggi tanaman, jumlah daun, jumlah cabang dan jumlah bunga.

3. Terdapat interaksi pengaruh pupuk NPK dan kapur dolomit terhadap berat basah dan berat kering. Berat basah dan berat kering paling tinggi dihasilkan dari pupuk NPK 5 $\mathrm{g} /$ tanaman dan kapur dolomit $15 \mathrm{~g} /$ tanaman.

\section{DAFTAR PUSTAKA}

Absori, Firkah. 2009. Tanah Masam dan Pengapuran. This Site Consists of Science Information. Bangka Belitung.

Agung, 2001. Pemberian Gambut Rawa Pening pada Tanah Latosol untuk Meningkatkan Pertumbuhan dan kandungan Gula pada Tanaman Stevia (Stevia rebaudiana Bertoni
M,). Skripsi. Institut Pertanian Bogor. Bogor.

Agus, F. dan I.G. M. Subiksa. 2008. Lahan Gambut: Potensi untuk Pertanian dan Aspek Lingkungan. Balai Penelitian Tanah dan World Agroforestry Centre (ICRAF), Bogor.

Balai Penelitian Tanah. 2010. Pengelolaan Lahan Gambut Berkelanjutan. Balai Penelitian Tanah, Balai Besar Litbang Sumberdaya Lahan Pertanian, Badan Penelitian dan Pengembangan Penelitian. Bogor.

Barchia, 2006. Release of phenolic acids and carbon from rice fields on Central Kalimantan peatlands, In: Peatlands for people; Natural Resource Functions and sustainable Management. Proceedings of the International Symposium on Tropical Peatlands, 22-23 Agustus 2006, Jakarta. J. O. Rieley and S.E. Page (eds.) with B. Setiadi. BPPT and Indonesian Peat Association. Pp 75-80.

Badan Pusat Statistik (BPS). 2013. Produksi Tanaman Sayuran di Indonesia. Survey Pertanian tahun 2013. Statistic Indonesia. Jakarta.

Buckman, N. O., and Brady, N. C. 1982. The Nature and Properties of Soil. Macmilan Co. Mineapolis. Minessota. 567 p. Ilmu Tanah diterjemahkan Soegiman. Bhratara Karya Aksara. Jakarta.

Driessen, P.M., dan H. Suhardjo. 1976. Peat Soils. Pp:763-779. In:Soil and Rice. IRRI. Los Banos. Philippines.

Foth, H. D. 1994. Dasar-dasar Ilmu Tanah. Terjemahan S. Adisoemarto. Edisi VI. Erlangga. Jakarta.

Hardjowigeno, S. 2003. Ilmu Tanah. Akademika Pressindo. Bogor.

Kristijono, A. 2010. Pemanfaatan Gambut sebagai Media Tumbuh BITUMAN dalam Rangka Mendukung Kegiatan Rehabilitasi Lahan Kritis. Laporan Program Intensif Riset DIKTI. Pusat Teknologi Sumber Daya Lahan, Wilayah dan Mitigasi Bencana. Jakarta. 
Lakitan, Benyamin. 2007. Dasar-dasar Fisiologi Tumbuhan. Raja Grafindo Persada. Jakarta

Mansur dan K.S, Koko. 2000. Metode Penggunaan kapur pada Tanah Sulfat Masam. Buletin Teknik pertanian Vol. 5, Nomor 2.

Marsono dan Sigit P. 2002. Pupuk Akar, Jenis dan Aplikasi. Penebar Swadaya. Jakarta.

Mehlich, A., dkk. 1955. Soil Chemistry and Plant Nutrition, dalam F.E Bear. Chemistry of the soil. Reinhold Pub. New York.

Sabiham et al, 1989. Studies on peat in the coastal plains of Sumatra and Borneo: Part II: Tha clay mineralogical composition of sediments in coastal plains of Jambi and South Kalimantan. Souteast Asian Studies, 27 : 3554.Soepardi, G. 1983. Masalah kesuburan tanah di Indonesia. Departemen Ilmu-ilmu Tanah. Fakultas pertanian. IPB. Bogor.

Salisbury, F.B dan C.W. Ross. 1995. Fisiologi Tumbuhan Jilid 3. Penerjemah Diah R.
Lukman dan Sumaryono. ITB Press. Bandung.

Soepardi, G. 1983. Sifat dan Ciri Tanah. Jurusan Tanah. Fakultas Pertanian. Institut Pertanian Bogor. Bogor. 591p.

Susila, Anas D. 2006. Panduan Budidaya Tanaman Sayuran. Bagian Produksi Tanaman Departemen Agronomi dan Hortikultura Institut Pertanian Bogor. Bogor.

Wibisono I.T.C, Siboro L, Suryadiputra INN. 2005. Panduan Rehabilitasi dan Teknik Silvikultur di Lahan Gambut. Bogor: Proyek Climate Change, Forest and Peatland in Indonesia. Wetlands Internasional-Indonesia Programme and Wildlife Habitat Canada.

Wiryanta, B.T.W. 2003. Bertanam Tomat. PT Agromedia Pustaka. Jakarta. 